\title{
Analysis of the spine posture, mobility and strength in healthy individuals with and without scapular dyskinesis
}

\section{Análise da postura, mobilidade e força da coluna vertebral em indivíduos saudáveis com e sem discinese escapular}

Ruthe de Góes Xavier do Nascimento ${ }^{1}$, (Dícia Farias Braga Maciel ${ }^{1}$, (D Liziane Mafra Vale de Souza ${ }^{1}$, (D) Thaís Brazão Siqueira de Lima $^{1}$, iD Sandra Cristina de Andrade ${ }^{1}$, (D) Catarina de Oliveira Sousa ${ }^{1}$

1 Universidade Federal do Rio Grande do Norte UFRN

\section{Corresponding}

Catarina de Oliveira Sousa

E-mail: sousa.catarinaoliveira@gmail.com

Submitted: February 17, 2021

Accepted: March 23, 2021

\section{How to cite}

Nascimento RGX, Maciel NFB, Souza LMV, Lima TBS, Andrade SC, Sousa CO. Analysis of the spine posture, mobility and strength in healthy individuals with and without scapular dyskinesis. Acta Fisiatr. 2021:28(1):7-14

\subsection{6/issn.2317-0190.v28i1a182017}

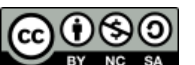

(C)2021 by Acta Fisiátrica

This work is licensed under a Creative Commons Attribution 4.0 International

\begin{abstract}
Spine posture, mobility and strength can be associated with changes in scapular movement and shoulder pain. However, these aspects have not been assessed in healthy individuals with scapular dyskinesis without shoulder and/or back pain. Objective: To analyze spine posture, mobility and strength in healthy individuals with and without scapular dyskinesis. Method: Cross-sectional study, fifty-two college-aged individuals were divided into two groups, according to scapular dyskinesis testing: a group without scapular dyskinesis $(n=19$; age= $22.95 \pm 2.86$ years; $\mathrm{BMI}=22.97 \pm 3.12 \mathrm{~kg} / \mathrm{m}^{2} ; 10$ males) and another with scapular dyskinesis $\left(n=33\right.$; age $=22.06 \pm 2.73$ years; $B M I=22.14 \pm 3.22 \mathrm{~kg} / \mathrm{m}^{2} ; 10$ males). Posture of the head and shoulders was analyzed from photographs by a postural assessment software (PAS/SAPO). Thoracic kyphosis and range of motion of the cervical and thoracolumbar spine were measured by a digital inclinometer, and the strength of the cervical and thoracolumbar spine muscles by a hand-held dynamometer. Intergroup comparison for all the variables was conducted using analysis of variance (one-way ANOVA), considering $p \leq 0.05$ as significant. Results: No intergroup difference was found for spine posture $(p=0.18-0.99)$, mobility $(p=$ $0.23-0.96)$ and strength $(p=0.42-0.99)$. Conclusion: Spine posture, mobility and strength do not differ between healthy individuals with and without scapular dyskinesis. The outcomes suggest that scapular dyskinesis may be related to interpersonal variations. Future prospective studies be conducted in order to verify if these variables can change and influence the development of shoulder pain.
\end{abstract}

Keywords: Shoulder Pain, Scapula, Posture, Rehabilitation

\section{RESUMO}

A postura, mobilidade e força da coluna podem estar associadas com mudanças no movimento da escápula e dor no ombro. No entanto, esses aspectos não foram avaliados em indivíduos saudáveis com discinese escapular sem dor no ombro e/ou nas costas. Objetivo: Analisar a postura da coluna vertebral, mobilidade e força em indivíduos saudáveis com e sem discinese escapular. Método: Estudo transversal com cinquenta e dois indivíduos em idade universitária foram divididos em dois grupos, de acordo com o teste de discinese escapular: um grupo sem discinese escapular ( $n=19$; idade $=22,95 \pm 2,86$ anos; IMC $=22,97 \pm 3,12 \mathrm{~kg} / \mathrm{m}^{2}$; 10 masculino) e outro com discinese escapular $(n=33$; idade $=22,06 \pm 2,73$ anos; IMC= $22,14 \pm 3,22 \mathrm{~kg} / \mathrm{m}^{2} ; 10$ masculino). A postura da cabeça e dos ombros foi analisada a partir de fotografias por um software de avaliação postural (PAS/SAPO). A cifose torácica e a amplitude de movimento da coluna cervical e torácica foram medidas por um inclinômetro digital, e a força dos músculos cervical e torác lombar por um dinamômetro portátil. A comparação intergrupo para todas as variáveis foi realizada utilizando-se a análise de variância (ANOVA unidirecional), considerando $\mathrm{p} \leq 0,05$ como significativa. Resultados: Não foi encontrada diferença entre grupos postura $(p=0,18-0,99)$, mobilidade $(p=0,23-0,96)$ e força da coluna $(p=0,42-0,99)$. Conclusão: Postura, mobilidade e força da coluna vertebral não diferem entre indivíduos saudáveis com e sem discinese escapular. Os resultados sugerem que a discinese escapular pode estar relacionada a variações interpessoais. Estudos prospectivos futuros devem ser conduzidos afim de verificar se essas variáveis podem modificar e influenciar o desenvolvimento da dor no ombro.

Palavras-chaves: Dor de Ombro, Escápula, Postura, Reabilitação 


\section{INTRODUCTION}

Scapular dyskinesis is characterized by alterations in the movement and/or position of the scapula. ${ }^{1}$ Some musculoskeletal factors that may be pointed as responsible for scapular dyskinesis are scapulothoracic muscles, due to dysfunctions in the activation ${ }^{2}$ and strength ${ }^{3}$ of the anterior serratus and lower trapezius and increased upper-trapezius muscle activity, ${ }^{2,4}$ as well as by reduction in muscle flexibility of the pectoralis minor, upper trapezius ${ }^{5}$ and scapular levator. ${ }^{6}$

These alterations are similar to those in scapular movement seen in individuals with subacromial impingement syndrome, ${ }^{7,8}$ which justified the importance of identifying these factors and scapular dyskinesis in the assessment of complex shoulder dysfunctions $^{9}$ for prevention and rehabilitation of shoulder pain and/or injuries. ${ }^{10}$ However, it is still controversial in the literature whether scapular dyskinesis may or may not be related to shoulder pain or injuries. Some studies assign scapular dyskinesis as risk factor for shoulder injuries ${ }^{11,12}$ while others show that, although scapular dyskinesis is a common condition, it cannot be considered a prospective risk factor for shoulder injuries. ${ }^{13,14}$

The prevalence of scapular dyskinesis has been very similar in individuals with and without shoulder pain, and it has been suggested that scapular dyskinesis can represent normal movement variability. ${ }^{15}$ This brings some insight into the fact that scapula dyskinesis may be related to other aspects than scapulothoracic muscles, such as spine posture, mobility and strength, since spine stability muscles are the functional center of the kinetic chain. ${ }^{16}$

Postural changes, such as forward-head and roundedshoulder posture ${ }^{17-19}$ and thoracic kyphosis, ${ }^{20}$ have been associated with alterations in shoulder movements and scapular kinematics during arm elevation. Nevertheless, scapular movements were measured in individuals simulating a slouched position ${ }^{17,18}$ or in individuals actually presenting postural changes. ${ }^{19} \mathrm{~A}$ wide age range (18-60 years) 19 or individuals older than 40 years 20 were included, which can influence postural and shoulder-movement alterations. ${ }^{20}$

Limited cervical extension and reduced cervical muscles endurance have been found in violin players presenting scapular dyskinesis, ${ }^{21}$ which may be due to the usual posture of the violin-playing activity accompanied by fatigue from the overuse of cervical muscles. ${ }^{21}$ Concerning the trunk, Pires \& Camargo $^{22}$ did not find any significant differences in the strength of the trunk flexors or of the lateral flexors between individuals with and without scapular dyskinesis; however, trunk-flexor muscle strength was approximately 5\% lesser in the scapular-dyskinesis group with a moderate effect, indicating that this can influence scapular dyskinesis ${ }^{22}$ even in young and healthy individuals. It is important to highlight that this study did not eliminate the influence of physical activity on its participants.

Thus, it is necessary to further the knowledge regarding the factors related to scapular dyskinesis in young and healthy individuals without any shoulder or cervical and thoracolumbar spine complaints who are not engaged in physical activities or specific labor activity, in order to eliminate the possible interference of age, pain, labor, sport and/or recreational pursuits. Identifying possible changes in spine posture, mobility and strength in individuals with scapular dyskinesis may indicate the biomechanical interrelationships between shoulder complex, trunk and neck and bring new perspectives for assessement of the scapula dyskinesis. In this perspective, the aim of this study was to compare spine posture, mobility and strength between young and healthy individuals with and without scapular dyskinesis. Our hypothesis is that, once excluding factors related to pain or complaints in the shoulder and/or spine and selected young individuals not involved with sports or specific labor activities that would overload the upper limbs, spine-related aspects would not differ between individuals with and without scapular dyskinesis.

\section{METHODS}

This is a cross-sectional study conducted at Department of Physical Therapy of Universidade Federal do Rio Grande do Norte - (UFRN) - Brazil. The study followed the STROBE (Strengthening the Reporting of Observational Studies in Epidemiology) guidelines, and its protocol was reviewed and approved by the Institutional Human Research Ethics Committee (under number 2.628.326) of UFRN. All participants provided written consent prior to participation.

Sample size was estimated a priori using the G*Power software, version 3.1.9.2, considering thoracic kyphosis as the main outcome variable, since thoracic kyphosis might influence shoulder movement and play an important role in the development of shoulder disorders. ${ }^{20} \mathrm{~A}$ power of $80 \%, \alpha=0.05$, a standard error of the measure of $2.4^{\circ}$, a standard deviation of $6.0^{\circ} 23$ and an expected mean difference of $5.0^{\circ}$ (twice the standard error described in Lewis \& Valentine ${ }^{23}$ ) were used to obtain a sample size of 19 individuals per group.

Individuals were recruited from flyers posted at the university, on its website and social media. Inclusion criteria were: males or females aged between 18 and 30 years; with no pain and/or shoulder or spine complaints; sedentary or irregularly active, according to the International Physical Activity Questionnaire (IPAQ) - Short Form. ${ }^{24}$

Exclusion criteria were: history of pain, soft tissue injury and/or shoulder or spinal fractures in the previous 12 months; prior shoulder, clavicle, humerus or spinal surgery; history of systemic connective, orthopedic or neurologic tissue disease; pain or symptoms of paresthesia during cervical compression tests; shoulder pain during arm elevation and in at least one of the following tests: Neer, Jobe, Gerber, Speed, Yeargson; scores above 14 (mild disability) on the neck disability index $(\mathrm{NDI})^{25}$ and on the Rolland-Morris disability questionnaire to assess lumbar spine function; ${ }^{26}$ shoulder pain $\geq 2$ at strenuous activities, according to the Pennsylvania Shoulder Score Questionnaire - Penn Score, since such score exceeds the minimal detectable change of 1.4 points for this measure, ${ }^{27}$ and subtle dyskinesis according to the scapular dyskinesis test, ${ }^{28}$ since it is characterized as mild or questionable evidence of scapular motion abnormality, not consistently present, ${ }^{28,29}$ and would hamper detection between-group differences.

Two researchers evaluated scapular dyskinesis, and a third one conducted the other assessments without knowing which groups the participants belonged to. Initially, the individuals completed a form for collection of demographics and measures of weight and height. They were assessed for inclusion criteria, 
including the scapular dyskinesis test, Penn Score, NDI, RollandMorris, IPAQ, and then, the posture of the head and shoulders, thoracic kyphosis and range of motion of the cervical and thoracolumbar spine were evaluated. The study evaluations were chosen in order to bring the evaluation closer to clinical practice, increasing the external validity of our results.

\section{Scapular Dyskinesis Assessment}

The scapular dyskinesis test (SDT), proposed by McClure et al. ${ }^{28}$ and validated by Tate et al. ${ }^{29}$ was used to assess the presence of scapular dyskinesis. Five consecutive bilateral repetitions of shoulder elevation movements in the sagittal and frontal planes were performed, with and without load. Participants weighing $\leq 68 \mathrm{~kg}$ sustained a load of $1.5 \mathrm{~kg}$, and those weighing $\geq 68.1 \mathrm{~kg}$, a load of $2.5 \mathrm{~kg}$. ${ }^{30}$ The test was filmed by a digital camera (Olympus, Model SP-800UZ, Tokyo, Japan) placed on a tripod two meters from the individuals at a level equivalent to $80 \%$ of their height.

According to the assessment, scapular movement was classified as normal, subtle or obvious dyskinesis, with normal scapular motion being characterized as no evidence of winging (the medial border and/or inferior angle of the scapula are posteriorly displaced away from the posterior thorax, and upper and lower rotations are smooth and continuous during arm elevation and lowering, respectively); obvious scapular dyskinesis being characterized as premature or excessive scapular elevation or protraction, nonsmooth or stuttering motion during arm elevation and lowering, as well as rapid scapular downward rotation during arm lowering or winging; and subtle dyskinesis being characterized as mild or questionable evidence of scapula motion abnormality. ${ }^{28}$

Obvious scapular dyskinesis was present if there was apparent abnormality evident on at least three out of five trials. ${ }^{28,29}$ This classification was previously shown to have moderate agreement between raters $([k=0.57]) .{ }^{28}$

Both evaluators underwent five hours of training to assess scapular dyskinesis according to SDT with 10 individuals in order to standardize the evaluation. Such training was coordinated by a physical therapist with 15 years' experience, who was also a third evaluator in case of disagreement between evaluators 1 and 2 . A video was used by evaluator 3 to classify the dyskinesis. That evaluator was consulted for nine individuals. A consensus was reached for all consultations, and all individuals were included in one of the groups.

For postural assessment, spherical Styrofoam markers (diameter $=1.5 \mathrm{~cm}$ ) were attached to the individual's skin with double-sided tape on: the tragus of both ears, the spinous process of the seventh vertebra (C7) and acromioclavicular joints. ${ }^{31,32}$ The corner of the eye was also used as a reference point, albeit without a marker. Flashless photographs were taken in right and left profile, with individuals at $30 \mathrm{~cm}$ from the wall. In order to avoid fictitious postural images, individuals were instructed to stand as normally as they could, with their arms extended along the body, and photographs were taken after some respiratory cycles.

The camera was positioned 1.5 meters from the wall at a level equivalent to $80 \%$ of the individual's height. Such height was established by the researchers since the aim was to assess only the upper-quadrant posture. Figure 1 shows the participants' positions and the markers used to measure postural angles. Angular analysis was conducted using postural assessment software (PAS/SAPO). ${ }^{33}$ In order to evaluate head position, the sagittal and cervical angles were measured so as to analyze extended posture and anteriorization, respectively. The shoulder angle was analyzed for shoulder position. ${ }^{31}$

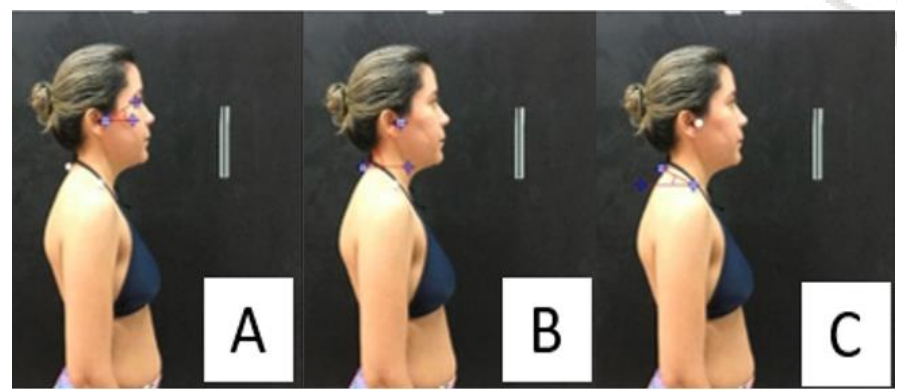

A: Sagittal head angle; B: Cervical angle; C: Shoulder angle

Figure 1. Participants' positions and markers used to measure postural angles

Thoracic kyphosis was analyzed using an Acumar digital inclinometer (Lafayette Instrument ${ }^{\circledR}$, IN, USA). Individuals were in a comfortable upright position with their arms relaxed by their sides and feet comfortably separated. Angulations were recorded by positioning the inclinometer at one point between the spinous processes of the first and second thoracic vertebrae ( $\alpha$ angle) and at one point between the spinous process of the twelfth thoracic vertebra and the spinous process of the first lumbar vertebra ( $\beta$ angle), (Figure $2-A, B$ ). Thoracic kyphosis was determined by the sum of $\alpha$ and $\beta$ angles. ${ }^{23}$ This procedure was validated by Barrett et al. ${ }^{34}$

\section{Range of motion (ROM)}

Range of motion (ROM) was measured using an Acumar digital inclinometer (Lafayette Instrument ${ }^{\circledR}$, IN, USA). For cervical spine flexion, extension, lateral flexion ROM, individuals were seated upright, stabilized trunk and their eyes focused straight ahead. The inclinometer was positioned vertically aligned with the external auditory meatus and then zeroed. Individuals were instructed to perform maximal neck flexion, extension, and both-side flexion (Figure 2 - C, D, and E).

For rotation, individuals were in supine with the neck in neutral position. The inclinometer was placed vertically on the top of the head aligned with the sagittal suture and individuals were instructed to rotate their neck in each direction as far as possible (Figure 2 - F). ${ }^{35}$ Each participant was asked to perform neck movements at his/her own pace without going too fast. ${ }^{35}$

A transparent $15 \mathrm{~cm}$ ruler was used during cervical extension and flexion measurements to support the base of the inclinometer in order to better align the device, given the irregularities of these anatomical surfaces.

Thoracolumbar flexion-extension and lateral flexion ROM were measured with the individuals' being in a comfortable upright position with their arms relaxed by their sides and feet comfortably separated. To measure flexion and extension, the inclinometer was positioned with its base in contact with the participant's skin and its center aligned with T12.

To measure lateral flexion, the base of the inclinometer was positioned at the T12 level and with its screens facing the investigator. Individuals were instructed to flex their trunk, moving to the limit of their ROM with their arms free (Figure 2 
- G). For extension, they were instructed to extend their trunk as far as they could, with their hands on their waist (Figure 2 H). For lateral flexion, they were asked to slide their hand down the side of their leg as far as possible while maintaining their trunk and head facing forward (Figure 2-1). ${ }^{36}$ Each movement was performed twice at the individual's desired speed. ${ }^{36}$

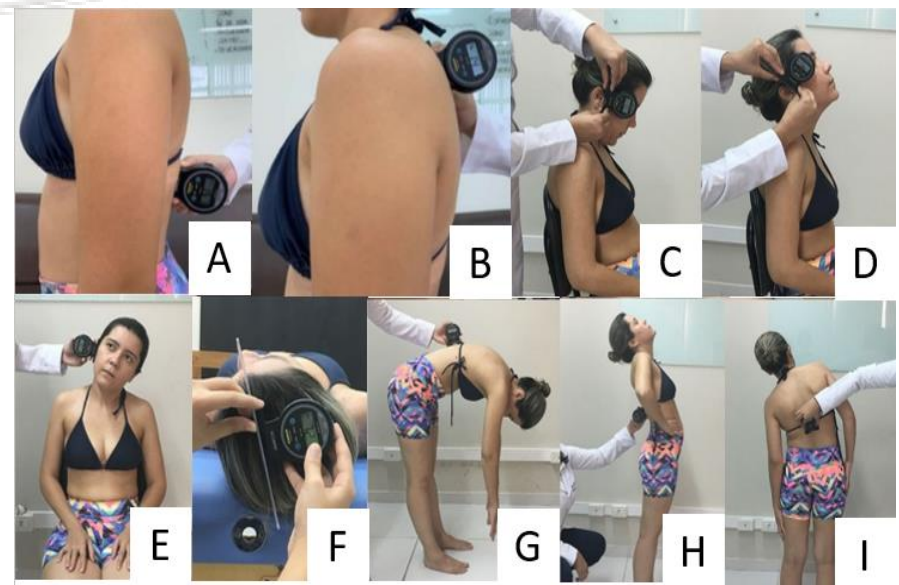

$A$ and $B$ : positions and assessment procedures for cervical and thoracolumbar range of motion; $C$ : cervical flexion; $D$ : cervical extension; $E$ : lateral cervical flexion; F: cervical rotation; $G$ : thoracolumbar flexion; $H$ : thoracolumbar extension; I: lateral thoracolumbar flexion

Figure 2. Assessment procedures for thoracic kyphosis

\section{Muscle strength}

Cervical spine and thoracolumbar flexor and extensor muscle strength was assessed using a hand-held dynamometer - Lafayette Manual Muscle Tester (Lafayette Instrument ${ }^{\circledR}$, IN, USA). The instrument was coupled to a nonelastic resistance band to measure isometric muscle strength. In addition to the band coupled to the dynamometer, other bands were used to stabilize the individual on the gurney, as shown in Figure 4, according to the muscle group tested.

For cervical and trunk flexor muscles, individuals were in supine, and the load cell of the dynamometer was positioned centered on the forehead ${ }^{37}$ and five $\mathrm{cm}$ below the sternal notch, ${ }^{22}$ respectively (Figure 3 - $A$ and $B$ ). For cervical and trunk extensor muscles, individuals were in prone, and the load cell of the dynamometer was positioned centered on the back of the head ${ }^{37}$ and on the midline between the two superior angles of the scapula, ${ }^{38}$ respectively (Figure 3 - C and D). Individuals were instructed to apply force into the direction of the action of each muscle group against the dynamometer.

All the measures were performed twice and each repetition lasted five seconds with a 30-second interval between them. To normalize peak strength, the value in kgf was divided by the weight $(\mathrm{kg})$ of each individual, multiplied by 100 and expressed as percentage of body weight (\%bw). ${ }^{22}$

\section{The evaluator's reliability}

Prior to the start of the study, ten healthy individuals were asked to repeat the procedures of postural assessment, ROM and strength for seven days in order to determine the evaluator's relative reliability. The intraclass correlation coefficient (ICC) varied from moderate to near perfect. ${ }^{39}$ ICCs were from 0.61 to 0.98 for posture variables, from 0.63 to 0.93 for ROM variables and from 0.65 to 0.99 for strength variables.
Means and standard deviations were calculated for all demographic and dependent variables, and for non-parametric variables, we included the range. The data were analyzed by the SPSS program, version 20.0 (SPSS Inc., Chicago, IL). The Shapiro-Wilk test was applied to evaluate normality of the variables. The Chi-squared test was applied to verify differences between groups for the gender and dominance.

The unpaired t-test was applied for height, BMS, posture of the head and shoulders, thoracic kyphosis and range of motion of the cervical and thoracolumbar spine. The Mann-Whitney test was applied for weight, PSS, neck disability index and Rolland-Morris disability. Effect sizes between groups were calculated for all outcomes using Cohen's d coefficient.

An effect size $>0.8$ was considered large; 0.5 was moderate, and $<0.2$ was small. ${ }^{40}$ Data analysis of the scapular dyskinesis group considered the measures of the dyskinesis side or that which was most evident. For the group without dyskinesis, the hemibody considered for analysis was randomly determined on the website www.random.org. The significance level adopted was $p<0.05$ for all tests.

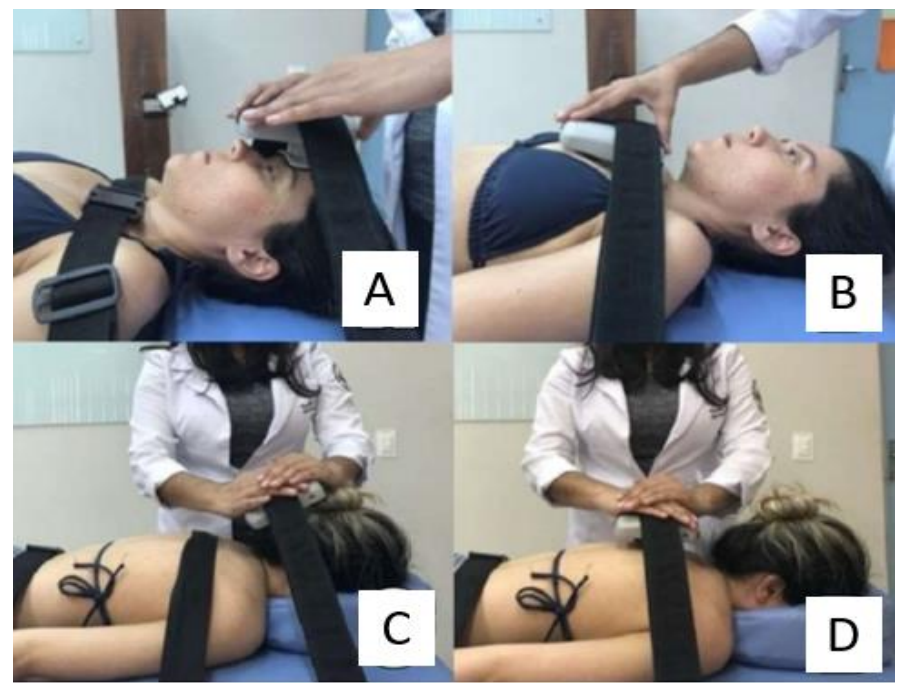

A: Neck flexor muscle test; B: Thoracolumbar flexor muscle test; C: Neck extensor muscle test; D: Thoracolumbar extensor muscle test

Figure 3. Positions and assessment procedures for cervical and core muscle strength

\section{RESULTS}

A total of 143 individuals were recruited. According to the eligibility criteria, 91 were excluded due to: shoulder pain $(n=$ $26)$, positive specific test for shoulder pain $(n=23)$, cervical or lumbar spine impairment/pain $(n=9)$, recent spine and/or shoulder injury $(n=6)$, physically active $(n=15)$, age $\geq 30$ years $(n=2)$, not returning to the assessments $(n=06)$, and presenting subtle dyskinesis $(n=4)$. Thus, 52 individuals were assigned to two groups: one with $(n=33)$ and one without $(n=19)$ scapular dyskinesis.

The demographic characteristics and variables related to the eligibility criteria for the sample are presented in Table 1. No difference was found between groups for any of these variables.

Table 2 shows the intergroup results of spine posture, where no difference was observed between individuals with and without scapular dyskinesis ( $p>0.05)$. 
Table 1. Demographic characteristics of participants

\begin{tabular}{|c|c|c|c|}
\hline Variables & $\begin{array}{l}\text { Group without dyskinesis } \\
\qquad(n=19)\end{array}$ & $\begin{array}{l}\text { Group with dyskinesis } \\
\qquad(n=33)\end{array}$ & $p$-value \\
\hline \multicolumn{4}{|l|}{ Sex } \\
\hline Male & 10 & 10 & 0.11 \\
\hline Female & 9 & 23 & \\
\hline Age (years) & $23.0 \pm 2.9(19.0-28.0)$ & $22.1 \pm 2.7(18.0-29.0)$ & 0.27 \\
\hline Weight (kg) & $67.3 \pm 12.9(55.1-106.0)$ & $61.9 \pm 11.4(48.0-91.0)$ & 0.48 \\
\hline Height (m) & $1.7 \pm 0.1(1.6-1.9)$ & $1.7 \pm 0.1(1.5-1.9)$ & 0.10 \\
\hline Body mass index $\left(\mathrm{kg} / \mathrm{m}^{2}\right)$ & $23.0 \pm 3.1(19.1-30.3)$ & $22.1 \pm 3.2(17.6-32.6)$ & 0.37 \\
\hline \multicolumn{4}{|l|}{ Dominance } \\
\hline Right & 19 & 30 & 0.18 \\
\hline Left & 0 & 3 & \\
\hline \multicolumn{4}{|l|}{ Dyskinesis side } \\
\hline Dominant & - & 18 & - \\
\hline Non-dominant & - & 15 & - \\
\hline Penn Score & $94.5 \pm 3.8(87.0-100.0)$ & $95.9 \pm 4.6(82.0-100.0)$ & 0.15 \\
\hline Neck Disability Index & $3.6 \pm 2.5(0.0-9.0)$ & $4.1 \pm 3.1(0.0-11.0)$ & 0.25 \\
\hline Roland-Morris Disability Questionnaire & $1.7 \pm 1.7(0.0-6.0)$ & $2.3 \pm 2.2(0.0-9.0)$ & 0.46 \\
\hline \multicolumn{4}{|c|}{ International Physical Activity Questionnaire (IPAQ) } \\
\hline Irregularly active & $17(89.47 \%)$ & $31(93.93 \%)$ & - \\
\hline Sedentary & $2(10.53 \%)$ & $2(6.07 \%)$ & - \\
\hline
\end{tabular}

Note: Age, height, and body mass index are expressed as meantstandard deviation; weight, Penn Score, Neck Disability Index, and Roland Morris Disability Questionnaire are expressed as meantstandard deviation (range); sex, dominance and International Physical Activity Questionnaire are expressed as number (percentage)

Table 2. Comparison of posture and muscle flexibility between groups with and without scapular dyskinesis

\begin{tabular}{lcccc}
\hline \multicolumn{1}{c}{ Variables } & $\begin{array}{c}\text { Group } \\
\text { without } \\
\text { dyskinesis } \\
\mathbf{n = 1 9}\end{array}$ & $\begin{array}{c}\text { Group } \\
\text { with } \\
\text { dyskinesis } \\
\mathbf{n}=\mathbf{3 3}\end{array}$ & p-value & Cohen's d \\
\hline Sagittal head angle $\left(^{\circ}\right)$ & $15.8 \pm 5.6$ & $15.8 \pm 8.2$ & 0.99 & 0.00 \\
Cervical angle $\left({ }^{\circ}\right)$ & $51.7 \pm 3.9$ & $50.2 \pm 4.0$ & 0.18 & 0.03 \\
Shoulder angle $\left({ }^{\circ}\right)$ & $26.0 \pm 13.7$ & $25.6 \pm 13.3$ & 0.91 & 0.01 \\
Thoracic kyphosis $\left(^{\circ}\right)$ & $33.3 \pm 8.3$ & $31.2 \pm 9.7$ & 0.44 & 0.03 \\
\hline
\end{tabular}

Note: Values expressed as mean \pm standard deviation; Legend: $\left({ }^{\circ}\right)$ - degrees; $\%$ ht - percentage of height

Table 3 shows the intergroup results of cervical and thoracolumbar range of motion, where no difference was found between individuals with and without scapular dyskinesis ( $p>0.05)$.

Table 3. Comparison of cervical and thoracolumbar range of motion variables between groups with and without scapular dyskinesis

\begin{tabular}{|c|c|c|c|c|}
\hline $\begin{array}{c}\text { Range of motion } \\
\text { variables }\left({ }^{\circ}\right)\end{array}$ & $\begin{array}{c}\text { Group without } \\
\text { dyskinesis } \\
n=19\end{array}$ & $\begin{array}{l}\text { Group with } \\
\text { dyskinesis } \\
n=33\end{array}$ & p-value & Cohen's d \\
\hline Cervical flexion & $37.9 \pm 11.3$ & $41.2 \pm 8.6$ & 0.23 & 0.06 \\
\hline $\begin{array}{l}\text { Cervical } \\
\text { hyperextension }\end{array}$ & $73.4 \pm 10.6$ & $72.6 \pm 12.3$ & 0.80 & 0.01 \\
\hline $\begin{array}{l}\text { Lateral cervical } \\
\text { flexion }\end{array}$ & $28.9 \pm 5.9$ & $28.9 \pm 5.7$ & 0.96 & 0.00 \\
\hline Cervical rotation & $67.1 \pm 11.2$ & $66.5 \pm 7.9$ & 0.84 & 0.01 \\
\hline $\begin{array}{l}\text { Thoracolumbar } \\
\text { flexion }\end{array}$ & $89.3 \pm 9.3$ & $88.0 \pm 15.0$ & 0.73 & 0.02 \\
\hline $\begin{array}{l}\text { Thoracolumbar } \\
\text { hyperextension }\end{array}$ & $32.1 \pm 9.5$ & $30.0 \pm 7.8$ & 0.40 & 0.04 \\
\hline
\end{tabular}

Table 4 shows the intergroup results of muscle strength, where no difference was observed between individuals with and without scapular dyskinesis ( $p>0.05)$.

Table 4. Comparison of cervical and thoracolumbar muscle strength between groups with and without scapular dyskinesis

\begin{tabular}{lcccc}
\hline \multicolumn{1}{c}{$\begin{array}{c}\text { Strength } \\
(\% \text { bw) }\end{array}$} & $\begin{array}{c}\text { Group without } \\
\text { dyskinesis } \\
\mathbf{n = 1 9}\end{array}$ & $\begin{array}{c}\text { Group with } \\
\text { dyskinesis } \\
\mathbf{n}=\mathbf{3 3}\end{array}$ & p-value & Cohen's d \\
\hline Cervical flexors & $9.7 \pm 2.5$ & $9.2 \pm 2.5$ & 0.53 & 0.06 \\
$\begin{array}{l}\text { Cervical } \\
\text { extensors }\end{array}$ & $15.1 \pm 3.5$ & $15.1 \pm 4.5$ & 0.99 & 0.01 \\
$\begin{array}{l}\text { Thoracolumbar } \\
\text { flexors }\end{array}$ & $19.3 \pm 5.8$ & $17.8 \pm 6.8$ & 0.42 & 0.02 \\
$\begin{array}{l}\text { Thoracolumbar } \\
\text { extensors }\end{array}$ & $19.7 \pm 5.3$ & $19.8 \pm 7.5$ & 0.99 & 0.04 \\
\hline
\end{tabular}

Note: Values expressed as mean \pm standard deviation; Legend: \% bw percentage of body weight

\section{DISCUSSION}

According to our hypothesis, young and healthy individuals, both with and without scapular dyskinesis, displayed similar spine posture, mobility, and muscle strength. These results are relevant, since we excluded all factors related to pain or complaints in the shoulder and/or spine and selected young individuals not involved with sports or specific labor activities that would overload the upper limbs, in order to eliminate any interference of pain, sport and/or leisure activities and age, thereby isolating the scapular dyskinesis factor.

It is important to underscore that the prevalence of scapular dyskinesis was substantial in our sample, where 33 of 52 individuals (63\%) displayed obvious dyskinesis, similar to reported by Hannah et al. ${ }^{41}$ that have reported in a prevalence of $67.5 \%$ of scapula dyskinesis in asymptomatic non-athletes. Although scapular dyskinesis is considered an important risk factor for developing shoulder pain even in athletes, ${ }^{12}$ its 
prevalence is very similar in partici-pants with and without shoulder pain, ${ }^{15}$ suggesting that it can also result from the normal variability of scapular movements. ${ }^{15,22}$

Alterations on spine posture, mobility and strength may be more related to shoulder and/or spine pain than to alterations in scapular position or movement. The relation between pain symptoms and changes in posture, especially thoracic kyphosis, has been observed in individuals with neck and shoulder pain. ${ }^{42,43}$ Individuals with greater thoracic kyphosis and forward head position exhibit greater neck disfunctions. ${ }^{43}$

Postural changes have affected shoulder mechanics, even in asymptomatic individuals, causing changes in shoulder movement and periscapular muscle activity. ${ }^{19,42}$ However, this may not appear in our individuals, even with scapular dyskinesis, because they are young and present a similar pattern of postural alignments as that of other asymptomatic and young individuals. ${ }^{44}$

The absence of intergroup differences in postural aspects may also extend to spinal range of motion, given that head position may exert a significant influence on spine motions. ${ }^{45}$

Reduced extension range of motion on the cervical spine is found in individuals with scapular dyskinesis who use the shoulder complex in their work-related activities, such as violinists. ${ }^{21}$ Since our individuals were not engaged in workrelated activities requiring upper-limb exertion, despite exhibiting scapular dyskinesis, their spine mobility presented, in general, a similar pattern to that of other asymptomatic and young individuals. ${ }^{35,36}$

Our individuals with and without scapular dyskinesis neither showed differences in the strength of cervical and trunk muscles. To our knowledge, this is the first study that has investigated alterations in cervical muscles strength in individuals with scapular dyskinesis. Lower resistance in these muscles was reported in individuals with scapular dyskinesis; however, the individuals evaluated were violin players. ${ }^{21}$

Regarding trunk-muscle strength, although Pires \& Camargo $^{22}$ did not identify significant differences between individuals with and without scapula dyskinesis either, they suggested that trunk strength seems to have influence on scapula dyskinesis. It is also seen that there is a relationship between the activation of the stabilizing muscles of the scapula and the flexor muscles of the thoracolumbar spine. ${ }^{46,47}$

However, our results cannot support this suggestion. Our results indicate that the variables related to spine posture, mobility and strength may not influence scapular dyskinesis when it is present in healthy and young individuals not involved with sports or specific labor activities that would overload the upper limbs. However, these variables should be kept under clinical evaluation in order to monitor individuals with scapular dyskinesis, since, in the long term, they can suffer alterations and become related to shoulder/neck pain or dysfunctions.

Our results should be analyzed considering some limitations: we have marked differences in male/female proportions in the groups and in the size of groups (19/33), however, the selection of the participants was by free demand, and we did not control these factors. In order to minimize possible influence of the sex in strength, we have normalized the force by the body weight. Also, strength was evaluated only based on strength peaks; however, individuals with dyskinesis may experience changes in muscle endurance in detriment to maximum strength performance. We suggest that future prospective studies be conducted in order to verify if these variables can change and influence the development of shoulder pain.

\section{CONCLUSION}

Our results indicated that spine posture, mobility and strength do not differ between healthy individuals with and without scapular dyskinesis.

\section{ACKNOWLEDGMENTS}

The authors are grateful to all the volunteers who contributed to this study.

\section{FUNDING}

The authors have received payment or services from a third party (government, commercial, private foundation, etc.) for any aspect of the submitted manuscript.

\section{REFERENCES}

1. Kibler WB, Ludewig PM, McClure PW, Michener LA, Bak K, Sciascia AD. Clinical implications of scapular dyskinesis in shoulder injury: the 2013 consensus statement from the 'Scapular Summit'. Br J Sports Med. 2013;47(14):877-85. Doi: http://dx.doi.org/10.1136/bjsports-2013-092425

2. Huang TS, Ou HL, Huang CY, Lin JJ. Specific kinematics and associated muscle activation in individuals with scapular dyskinesis. J Shoulder Elbow Surg. 2015;24(8):1227-34. Doi: http://dx.doi.org/10.1016/j.jse.2014.12.022

3. Seitz AL, McClelland RI, Jones WJ, Jean RA, Kardouni JR. A comparison of change in $3 \mathrm{~d}$ scapular kinematics with maximal contractions and force production with scapular muscle tests between asymptomatic overhead athletes with and without scapular dyskinesis. Int J Sports Phys Ther. 2015;10(3):309-18.

4. Lopes $A D$, Timmons $M K$, Grover $M$, Ciconelli RM, Michener LA. Visual scapular dyskinesis: kinematics and muscle activity alterations in patients with subacromial impingement syndrome. Arch Phys Med Rehabil. 2015;96(2):298-306.

http://dx.doi.org/10.1016/j.apmr.2014.09.029

5. Yeşilyaprak SS, Yüksel E, Kalkan S. Influence of pectoralis minor and upper trapezius lengths on observable scapular dyskinesis. Phys Ther Sport. 2016;19:7-13. Doi: http://dx.doi.org/10.1016/j.ptsp.2015.08.002

6. Lee JH, Cynn HS, Choi WJ, Jeong HJ, Yoon TL. Reliability of levator scapulae index in subjects with and without scapular downward rotation syndrome. Phys Ther Sport. 2016;19:1-6.

Doi: http://dx.doi.org/10.1016/i.ptsp.2015.07.002

7. Ludewig PM, Braman JP. Shoulder impingement: biomechanical considerations in rehabilitation. Man Ther. 2011;16(1):33-9.

Doi: http://dx.doi.org/10.1016/j.math.2010.08.004 
8. Timmons MK, Thigpen CA, Seitz AL, Karduna AR, Arnold BL, Michener LA. Scapular kinematics and subacromialimpingement syndrome: a meta-analysis. J Sport Rehabil. 2012;21(4):354-70. Doi: http://dx.doi.org/10.1123/jsr.21.4.354

9. Cools AM, Cambier D, Witvrouw EE. Screening the athlete's shoulder for impingement symptoms: a clinical reasoning algorithm for early detection of shoulder pathology. Br J Sports Med. 2008;42(8):628-35. Doi: http://dx.doi.org/10.1136/bjsm.2008.048074

10. Andersson SH, Bahr R, Clarsen B, Myklebust G. Preventing overuse shoulder injuries among throwing athletes: $A$ cluster-randomised controlled trial in 660 elite handball players. Br J Sports Med. 2017;51(14):1073-80. Doi: http://dx.doi.org/10.1136/bjsports-2016-096226

11. Clarsen B, Bahr R, Andersson SH, Munk R, Myklebust G. Reduced glenohumeral rotation, external rotation weakness and scapular dyskinesis are risk factors for shoulder injuries among elite male handball players: a prospective cohort study. $\mathrm{Br} J$ Sports Med. 2014;48(17):1327-33.

http://dx.doi.org/10.1136/bjsports-2014-093702

12. Hickey D, Solvig V, Cavalheri V, Harrold M, Mckenna L. Scapular dyskinesis increases the risk of future shoulder pain by $43 \%$ in asymptomatic athletes: a systematic review and meta-analysis. $\mathrm{Br} J$ Sports Med. 2018;52(2):102-10.

http://dx.doi.org/10.1136/bjsports-2017-097559

13. Myers JB, Oyama S, Hibberd EE. Scapular dysfunction in high school baseball players sustaining throwing-related upper extremity injury: A prospective study. J Shoulder Elb Surg. 2013;22(9):1154-9. Doi: http://dx.doi.org/10.1016/j.jse.2012.12.029

14. Andersson SH, Bahr R, Clarsen B, Myklebust G. Risk factors for overuse shoulder injuries in a mixed-sex cohort of 329 elite handball players: previous findings could not be confirmed. Br J Sports Med. 2018;52(18):1191-8. Doi: http://dx.doi.org/10.1136/bjsports-2017-097648

15. Plummer HA, Sum JC, Pozzi F, Varghese R, Michener LA. Observational scapular dyskinesis: known-groups validity in patients with and without shoulder pain. J Orthop Sports Phys Ther. 2017;47(8):530-7. Doi: http://dx.doi.org/10.2519/jospt.2017.7268

16. Akuthota V, Nadler SF. Core strengthening. Arch Phys Med Rehabil. 2004;85(3):S86-92. Doi: http://dx.doi.org/10.1053/j.apmr.2003.12.005

17. Kebaetse $M$, McClure $P$, Pratt NA. Thoracic position effect on shoulder range of motion strength, and threedimensional scapular kinematics. Arch Phys Med Rehabil. 1999;80(8):945-50. http://dx.doi.org/10.1016/s0003-9993(99)90088-6

18. Finley MA, Lee RY. Effect of sitting posture on 3dimensional scapular kinematics measured by skinmounted electromagnetic tracking sensors. Arch Phys Med Rehabil. 2003;84(4):563-8. Doi: http://dx.doi.org/10.1053/i.apmr.2003.12.005
19. Thigpen CA, Padua DA, Michener LA, Guskiewicz K, Giuliani C, Keener JD, et al. Head and shoulder posture affect scapular mechanics and muscle activity in overhead tasks. J Electromyogr Kinesiol. 2010;20(4):701-9. Doi: http://dx.doi.org/10.1016/i.jelekin.2009.12.003

20. Otoshi K, Takegami M, Sekiguchi M, Onishi Y, Yamazaki S, Otani K, et al. Association between kyphosis and subacromial impingement syndrome: LOHAS study. J Shoulder Elb Surg. 2014;23(12):e300-7. Doi: http://dx.doi.org/10.1016/i.jse.2014.04.010

21. Tawde P, Dabadghav R, Bedekar N, Shyam A, Sancheti P. Assessment of cervical range of motion, cervical core strength and scapular dyskinesia in violin players. Int J Occup Saf Ergon. 2016;22(4):572-576. Doi: http://dx.doi.org/10.1080/10803548.2016.1181892

22. Pires ED, Camargo PR. Analysis of the kinetic chain in asymptomatic individuals with and without scapular dyskinesis. Clin Biomech (Bristol, Avon). 2018;54:8-15. Doi: http://dx.doi.org/10.1016/j.clinbiomech.2018.02.017

23. Lewis JS, Valentine RE. Clinical measurement of the thoracic kyphosis. A study of the intra-rater reliability in subjects with and without shoulder pain. BMC Musculoskelet Disord. 2010;11:39. Doi: http://dx.doi.org/10.1186/1471-2474-11-39

24. Lee PH, Macfarlane DJ, Lam TH, Stewart SM. Validity of the International Physical Activity Questionnaire Short Form (IPAQ-SF): a systematic review. Int J Behav Nutr Phys Act. 2011;8:115. Doi: http://dx.doi.org/10.1186/14795868-8-115

25. Vernon $\mathrm{H}$, Mior S. The Neck Disability Index: a study of reliability and validity. I Manipulative Physiol Ther. 1991;14(7):409-15.

26. Nusbaum L, Natour J, Ferraz MB, Goldenberg J. Translation, adaptation and validation of the RolandMorris questionnaire-Brazil Roland-Morris. Braz J Med Biol Res. 2001;34(2):203-10. Doi: http://dx.doi.org/10.1590/s0100-879x2001000200007

27. Leggin BG, Michener LA, Shaffer MA, Brenneman SK, lannotti JP, Williams GR Jr. The Penn shoulder score: reliability and validity. J Orthop Sports Phys Ther. 2006;36(3):138-51. http://dx.doi.org/10.2519/jospt.2006.36.3.138

28. McClure $P$, Tate AR, Kareha S, Irwin D, Zlupko E, McClure $P$, et al. A clinical method for identifying scapular dyskinesis, part 1: reliability. J Athl Train. 2009;44(2):1604. Doi: http://dx.doi.org/10.4085/1062-6050-44.2.160

29. Tate AR, McClure P, Kareha S, Irwin D, Barbe MF. A clinical method for identifying scapular dyskinesis, part 2: validity. J Athl Train. 2009;44(2):165-73. Doi: http://dx.doi.org/10.4085/1062-6050-44.2.165

30. Rossi DM, Resende RA, da Fonseca ST, de Oliveira AS. Scapulothoracic kinematic pattern in the shoulder pain and scapular dyskinesis: A principal component analysis approach. J Biomech. 2018;77:138-145. doi: http://dx.doi.org/10.1016/i.jbiomech.2018.07.010 
31. Ruivo RM, Pezarat-Correia P, Carita Al. Cervical and shoulder postural assessment of adolescents between 15 and 17 years old and association with upper quadrant pain. Braz J Phys Ther. 2014;18(4):364-71. Doi: http://dx.doi.org/10.1590/bjpt-rbf.2014.0027

32. Singla D, Veqar Z, Hussain ME. Photogrammetric assessment of upper body posture using postural angles: a literature review. J Chiropr Med. 2017;16(2):131-8. Doi: http://dx.doi.org/10.1016/j.jcm.2017.01.005

33. Ferreira EAG, Duarte $M$, Maldonado EP, Burke TN, Marques AP. Postural assessment software (PAS/SAPO): validation and reliabiliy. Clinics. 2010;65(7):675-81. Doi: http://dx.doi.org/10.1590/S1807-59322010000700005

34. Barrett E, O'Keeffe M, O'Sullivan K, Lewis J, McCreesh K. Is thoracic spine posture associated with shoulder pain, range of motion and function? a systematic review. Man Ther. 2016;26:38-46. Doi: http://dx.doi.org/10.1016/j.math.2016.07.008

35. Tousignant-Laflamme $Y$, Boutin N, Dion AM, Vallée CA. Reliability and criterion validity of two applications of the iPhone $^{\mathrm{TM}}$ to measure cervical range of motion in healthy participants. J Neuroeng Rehabil. 2013;10(1):14-20. Doi: http://dx.doi.org/10.1186/1743-0003-10-69

36. Macedo LB, Borges DT, Melo SA, Costa KSA, Sousa CO, Brasileiro JS. Reliability and concurrent validity of a mobile application to measure thoracolumbar range of motion in low back pain patients. J Back Musculoskelet Rehabil. 2020;33(1):145-51. Doi: http://dx.doi.org/10.3233/BMR181396

37. Shahidi B, Johnson CL, Curran-Everett D, Maluf KS. Reliability and group differences in quantitative cervicothoracic measures among individuals with and without chronic neck pain. BMC Musculoskelet Disord. 2012;13:215. Doi: http://dx.doi.org/10.1186/1471-2474$\underline{13-215}$

38. Valentin G, Maribo T. Hand-held dynamometry fixated with a tripod is reliable for assessment of back extensor strength in women with osteoporosis. Osteoporos Int. 2014;25(8):2143-9.

Doi:
39. Landis JR, Koch GG. The measurement of observer agreement for categorical data. Biometrics. 1977;33(1):159-74.

40. Cohen J. The concepts of power analysis. In: Cohen J. Statistical power analysis for the behavioral sciences. Hillsdale, NJ: Lawrence Erlbaum Associates; 1988. p. 1-17.

41. Hannah DC, Scibek JS, Carcia CR. Strength profiles in healthy individuals with and without scapular dyskinesis. Int J Sports Phys Ther. 2017;12(3):305-13.

42. Malmström EM, Olsson J, Baldetorp J, Fransson PA. A slouched body posture decreases arm mobility and changes muscle recruitment in the neck and shoulder region. Eur J Appl Physiol. 2015;115(12):2491-503. Doi: http://dx.doi.org/10.1007/s00421-015-3257-y

43. Quek J, Pua YH, Clark RA, Bryant AL. Effects of thoracic kyphosis and forward head posture on cervical range of motion in older adults. Man Ther. 2013;18(1):65-71. Doi: http://dx.doi.org/10.1016/j.math.2012.07.005

44. Lewis JS, Green A, Wright C. Subacromial impingement syndrome: The role of posture and muscle imbalance. J Shoulder Elb Surg. 2005;14(4):385-92. Doi: http://dx.doi.org/10.1016/j.jse.2004.08.007

45. Schinkel-Ivy A, Pardisnia S, Drake JDM. Head and arm positions that elicit maximal voluntary trunk range-ofmotion measures. J Appl Biomech. 2014;30(6):689-96. Doi: http://dx.doi.org/10.1123/jab.2013-0247

46. Vega Toro AS, Cools AMJ, de Oliveira AS. Instruction and feedback for conscious contraction of the abdominal muscles increases the scapular muscles activation during shoulder exercises. Man Ther. 2016;25:11-8. Doi: http://dx.doi.org/10.1016/j.math.2016.05.331

47. Shiravi S, Letafatkar A, Bertozzi L, Pillastrini P, Khaleghi Tazji M. Efficacy of abdominal control feedback and scapula stabilization exercises in participants with forward head, round shoulder postures and neck movement impairment. Sports Health. 2019;11(3):272-9. Doi: http://dx.doi.org/10.1177/1941738119835223 